\title{
Molecularly imprinted nanoparticles for inhibiting ribonuclease in reverse transcriptase polymerase chain reaction
}

\author{
Feng, Xiaotong; Ashley, Jon; Zhou, Tongchang; Halder, Arnab; Sun, Yi
}

Published in:
Analyst

Link to article, DOI:

10.1039/c8an00711j

Publication date:

2018

Document Version

Peer reviewed version

Link back to DTU Orbit

Citation (APA):

Feng, X., Ashley, J., Zhou, T., Halder, A., \& Sun, Y. (2018). Molecularly imprinted nanoparticles for inhibiting ribonuclease in reverse transcriptase polymerase chain reaction. Analyst, 143(12), 2750-2754.

https://doi.org/10.1039/c8an00711j

\section{General rights}

Copyright and moral rights for the publications made accessible in the public portal are retained by the authors and/or other copyright owners and it is a condition of accessing publications that users recognise and abide by the legal requirements associated with these rights.

- Users may download and print one copy of any publication from the public portal for the purpose of private study or research.

- You may not further distribute the material or use it for any profit-making activity or commercial gain

- You may freely distribute the URL identifying the publication in the public portal

If you believe that this document breaches copyright please contact us providing details, and we will remove access to the work immediately and investigate your claim. 


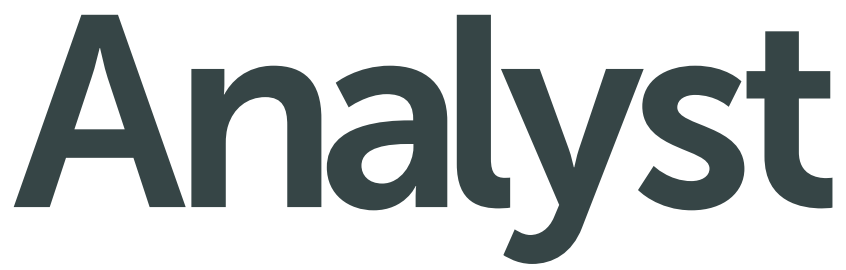

\section{Accepted Manuscript}

This article can be cited before page numbers have been issued, to do this please use: X. Feng, J. Ashley,

T. Zhou, A. Halder and Y. Sun, Analyst, 2018, DOI: 10.1039/C8AN00711J.

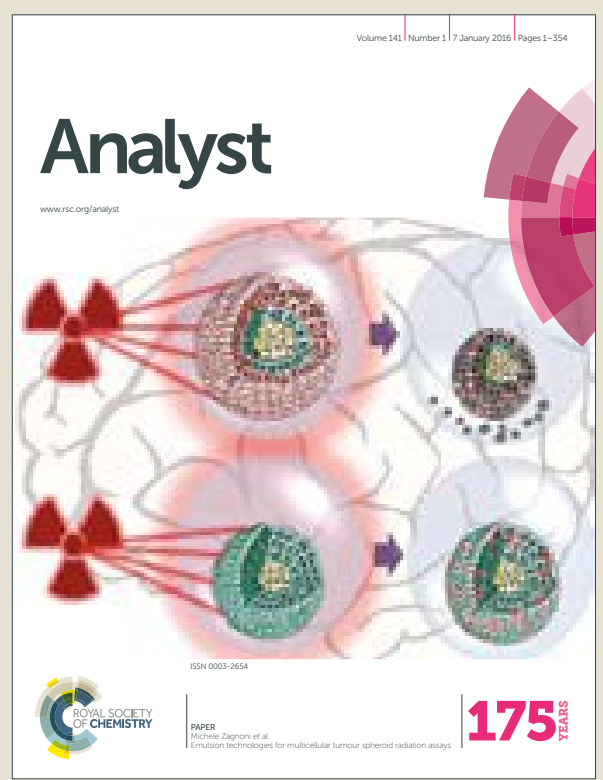

This is an Accepted Manuscript, which has been through the Royal Society of Chemistry peer review process and has been accepted for publication.

Accepted Manuscripts are published online shortly after acceptance, before technical editing, formatting and proof reading. Using this free service, authors can make their results available to the community, in citable form, before we publish the edited article. We will replace this Accepted Manuscript with the edited and formatted Advance Article as soon as it is available.

You can find more information about Accepted Manuscripts in the author guidelines

Please note that technical editing may introduce minor changes to the text and/or graphics, which may alter content. The journal's standard Terms \& Conditions and the ethical guidelines, outlined in our author and reviewer resource centre, still apply. In no event shall the Royal Society of Chemistry be held responsible for any errors or omissions in this Accepted Manuscript or any consequences arising from the use of any information it contains. 


\section{Received 00th January 20xx,} Accepted 00th January 20xx

DOI: $10.1039 / x 0 x \times 00000 x$

\section{Molecularly Imprinted Nanoparticles for Inhibiting Ribonuclease in Reverse Transcriptase Polymerase Chain Reaction}

www.rsc.org/

Molecularly imprinted nanoparticles (nanoMIPs) are synthesized via a solid-phase approach using RNase as the template. The feasibility of employing the nanoMIPs as RNase inhibitor is successfully demonstrated in reverse transcriptase polymerase chain reaction (RT-PCR) assays, suggesting the tailor-made nanomaterials are very promising for use in routine biological assays.

Reverse transcriptase polymerase chain reaction (RT-PCR) is considered as the gold standard in quantifying RNA. It has found widespread use in food and environmental analysis as well as medical diagnostics. ${ }^{1-4}$ However, the accuracy of RT-PCR can be severely affected by the presence of Ribonucleases (RNases), a ubiquitous enzyme in living organisms that can degrade RNA and compromise RNA integrity. ${ }^{5}$ As such, RNase inhibitors are often added in RT-PCR to protect RNA from degradation by RNases. Small molecules such as oligomers of vinylsulfonic acid (OVS) and pyrophosphate-linked oligonucleotide (pdUppA-3-p) can inhibit RNases, but the production is difficult and they are susceptible to hydrolysis. ${ }^{6-8}$ Metal ions also exhibit inhibitory effect by acting as a transition state analog, whereas they tend to bind with RNA which would interrupt the RT-qPCR assay. ${ }^{9,10}$ The most commonly used RNases inhibitors are the nature/recombinant proteins which can form a tight 1:1 complex with RNases and render them inactive. ${ }^{11,12}$ Despite the high efficiency, these proteins are expensive and have relatively short shelf-lives due to their biological origin.

Recently, nanomaterials have been increasingly used in bioassays. A particularly exciting area of research is molecularly imprinted polymers (MIPs). Molecular imprinting is a generic approach for generating a polymer matrix with binding sites that are structurally and functionally complementary to its template. ${ }^{13-15}$ Encouraged by the extraordinary molecular recognition capability, many researchers have exploited MIPs in sample preparation and biosensing to capture

Department of Micro- and Nanotechnology, Technical University of Denmark, Ørsteds Plads, DK- 2800 Kgs, Lyngby, Denmark

E-mail: Sun.Yi@nanotech.dtu.dk

Electronic Supplementary Information (ESI) available: [details of any supplementary information available should be included here]. See DOI: $10.1039 / \mathrm{x} 0 \times x \times 0000 \mathrm{x}$ targets ranging from small molecules to big proteins. ${ }^{16-18}$ Lately, some groups have reported that the MIPs could inhibit their enzyme templates owing to the ability to trigger specific molecular interactions. ${ }^{19-21} \mathrm{~A}$ pioneer work by Cutivet et. al. indicated that MIP microgels imprinted for trypsin could bind the enzyme and significantly reduce its enzymatic activity. ${ }^{19}$ Zhang et. al. also demonstrated the synthesis of hydrophilic MIP microspheres with trypsin inhibition potency. ${ }^{20}$ Liu et. al. showed that the MIPs could specifically and reversibly block the activity of DNase I in complex biological samples. ${ }^{21}$ These findings suggested that MIPs possess enormous potential to function as a new class of enzyme inhibitors. This is very exciting, as compared to protein inhibitors, MIPs offer additional advantages including easy design, high thermal stability, and robustness, as well as low fabrication cost. However, up to now, the exploration of MIPs as enzyme inhibitors has been limited to proof-ofconcept only, and their applications in real biological reactions have seldom been demonstrated.

In this study, we proposed for the first time, to use MIPs nanoparticles (nanoMIPs) as RNase A inhibitors in the RT-PCR assay (Fig. 1). The nanoMIPs were synthesized via a solid-phase approach, and cavities with complementary shape, size and functional groups to the template were formed on the surface (Fig. S1 †). They could interact with the RNase $\mathrm{A}$ at multiple binding sites which also include the active sites of the RNase A, thereby blocking the enzymatic activity and preventing RNA degradation. The formulation of the nanoMIPs was optimized by screening commonly used functional monomers. When added to the RT-PCR assay, the nanoMIPs managed to inhibit $10 \mathrm{ng}$ of RNase A in a $10 \mu \mathrm{L}$-reaction. Moreover, the nanoMIPs did not interfere with other enzymes such as RNA reverse transcriptase and DNA polymerase. Since only a trace amount of RNase A (sub ng) is expected to be present in an RT-PCR reaction, the nanoMIPs could in principle replace the commercial recombinant protein inhibitors. With the competitive inhibition behavior, we believe the tailor-made nanomaterials are very promising for a variety of biological and biomedical applications. 


\section{Journal Name}

\section{COMMUNICATION}

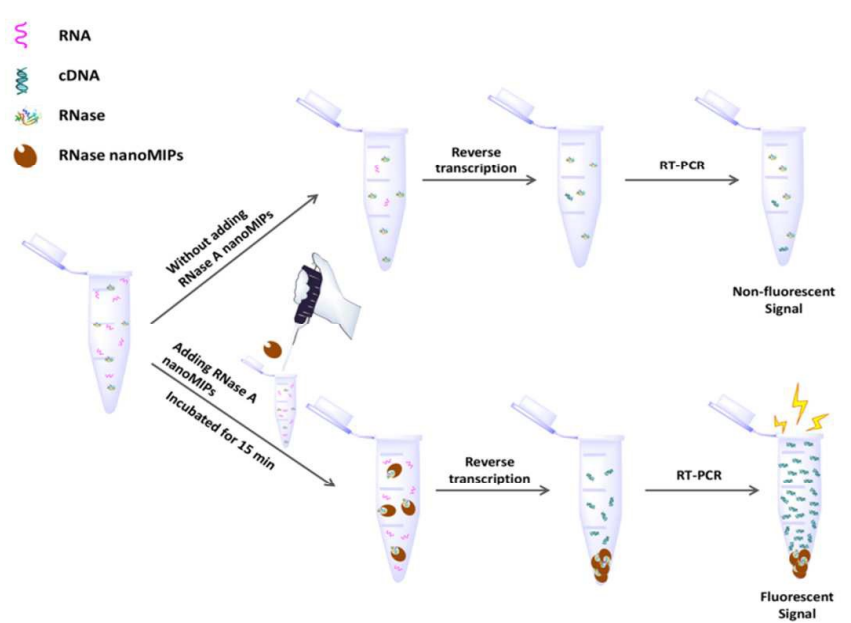

Fig. 1 Schematic illustration of the use of RNase A nanoMIPs in RT-PCR assay. RNase A can degrade RNA and compromise RNA integrity, which severely affects the accuracy of RT-PCR (upper part). The nanoMIPs have cavities that are complementary in shape, size and functional groups of RNase A. They could interact with the RNase A at multiple binding sites, thereby blocking the enzymatic activity and preventing RNA degradation in the RT-PCR assay (lower part).

In this work, RNase A was used as the model template and a solidphase approach was chosen to synthesize the nanoMIPs (Fig. S1†). Traditional MIP synthesis methods, such as suspension polymerization and emulsion polymerization, were not suitable for this application, as the templates could hardly be completely removed from the nanoMIPs due to the equilibrium balance between the template and polymer matrix. The leakage of RNase A template could act as a potential source of contamination to the RT-PCR assay. In contrast, in the solid-phase synthesis, the template was immobilized on the surface of glass beads. ${ }^{22}$ The reaction mixture containing monomers, initiator and crosslinker was then added, and the nanoMIPs were formed around the RNase A template during the polymerization. After synthesis, the unreacted monomers and low-affinity nanoMIPs were washed away, and high-affinity nanoMIPs were separated from the templates by a hot elution. Therefore, the resultant nanoMIPs were templatefree and endowed with homogenous and high-affinity binding sites.

RNase A is a basic protein with an isoelectric point (pI) of 9.6 and a molecular weight of $13.7 \mathrm{kDa}$. It contains 19 of the 20 natural amino acids (excluding tryptophan) and is made up of a single polypeptide chain of 124 amino acid residues. The proton transfer between two histidines (His 12 and His 119) active sites of RNase A and phosphodiester bond and phosphate group of RNA can cause degradation of RNA. ${ }^{23}$ Therefore, in order to efficiently inhibit RNase A, it is crucial for the nanoMIPs to bind to the active sites of the enzyme. Since the composition of the functional monomers has a great impact on the binding behavior of the nanoMIPs, we synthesized a small library of nanoMIPs with various monomer ratios in order to find the optimized formulation (Table. S1†).
Herein, N-isopropyl acrylamide (NIPAm) was employed as a backbone monomer. Acrylic acid $(\mathrm{AAc})\left(\mathrm{pK}_{\mathrm{a}}=4.7\right)$ was chosen to interact with positively-charged residues (e.g. $\alpha$-amino group from histidine). N-tert-Butylactylamide (TBAm) was utilized to interact with hydrophobic residues of RNase A. Methacrylamide (AAm) was used to provide hydrogen bond (e.g., interacting with nitrogen in the imidazole ring of histidine). Their inhibitory potency towards RNase A was measured using the RNase A activity kit as shown in Figure. 2a. The inhibition efficiency of nanoMIP 2 was higher than nanoMIP 1, suggesting that hydrophobic interactions via TBAm were beneficial for inactivating the RNase A. Though RNase A is a polar molecule, the major and the minor dimers are made up mainly of apolar side chains. ${ }^{24}$ The hydrophobic interactions with TBAm could enhance the binding specificity, which in turn contributed to the inhibition efficiency. By further decreasing the amount of AAc and increasing the amount of TBAm, nanoMIP 3 showed better inhibition than nanoMIP 2. This might be because the non-specific electrostatic interaction caused by the negatively-charged AAc was much reduced. Moreover, nanoMIP 4 was further improved by adding 5\% AAm. This was possibly attributed to the fact that AAm could provide hydrogen interactions with the histidine at the active sites of the RNase A. Taken together, these results indicated that the proper combination of hydrophobic, hydrogen and negativelycharged functional groups is essential for forming nanoMIPs with high inhibition efficiency. Therefore, nanoMIP 4 with the composition of $50 \mathrm{~mol} \%$ NIPAm, $5 \mathrm{~mol} \%$ AAm, $5 \mathrm{~mol} \%$ AAc, 38 mol\% TBAm and $2 \mathrm{~mol} \%$ BIS (N,N'-Methylenebis(acrylamide)) was selected for the further experiments. 
The yield, size, and morphology of nanoMIPs 4 were then characterized. A typical solid-phase reaction utilized $25 \mathrm{~g}$ glass beads. The amount of RNase A immobilized on per gram of glass beads was $6.37 \mathrm{nmol}$ as determined by bicinchoninic acid assay (BCA)-based protein assay (Fig. S2 $\dagger$ ). The yield of high-affinity nanoparticles obtained was $0.58 \mathrm{mg} \mathrm{g}^{-1}$ glass beads or $14.5 \mathrm{mg}$ per reaction. The scanning electron microscopy (SEM) image of nanoMIP 4 showed spherical nanoparticles with sizes ranging from 100 to $200 \mathrm{~nm}$ (Fig. S3a $†$ ), which was smaller than that measured by dynamic light scattering (DLS) (Fig. S3b $\dagger$ ). This could be due to the fact that the nanoparticles shrank upon drying.

We further investigated the binding capacity, kinetics, and selectivity of nanoMIP 4. The binding capacity of the nanoMIP for RNase A was determined by equilibrium binding assays. The isotherm curve was shown in Fig. S4a. The adsorption of RNase A to nanoMIPs 4 $\left(5 \mathrm{mg} \mathrm{mL}^{-1}\right)$ increased rapidly with the increment of RNase A concentration. The saturation was reached at $25 \mu \mathrm{g} \mathrm{mL}^{-1}$. Based on the Scatchard plot (Fig. S5), the dissociation constant Kd and Qmax were calculated to be $3.2 \mu \mathrm{g} \mathrm{mL}^{-1}\left(237 \mathrm{nM}\right.$ ) and $4.98 \mu \mathrm{g} \mathrm{mg}^{-1}$ (364 nmol g${ }^{-1}$ ), respectively. The binding capacity of the nanoMIP was

(a)

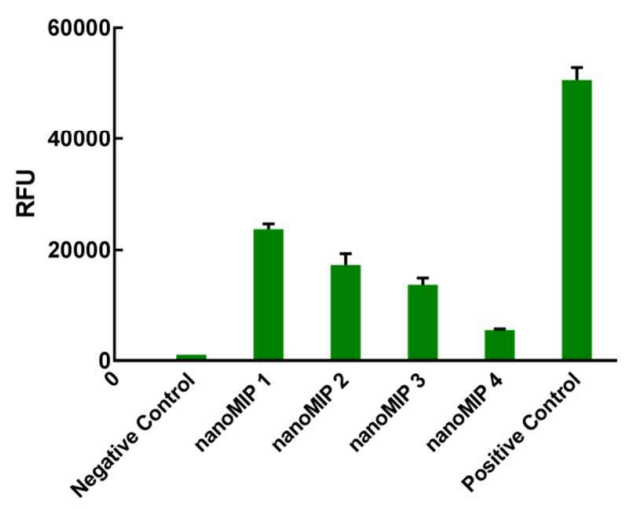

(b)

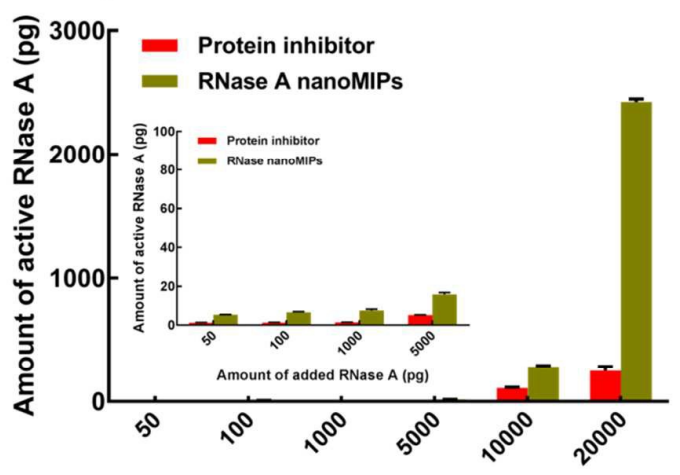

Amount of added RNase A (pg)

Fig. 2 (a) Inhibitory effect of nanoMIPs (different monomer compositions) towards RNase A. (b) Comparison of the inhibitory potency of the protein inhibitor and the nanoMIP 4. Insert refers to the magnification of the plot in the range of $50 \mathrm{pg}$ to $5000 \mathrm{pg}$. relatively low when compared to MIPs synthesized by other methods. This was because, for solid-phase synthesis, only one imprinted cavity was formed on the surface of single nanoMIPs. The binding kinetics of the nanoMIP was shown in Fig. S4b. The binding between RNase A $\left(5 \mu \mathrm{g} \mathrm{mL}^{-1}\right)$ and nanoMIPs $4\left(5 \mathrm{mg} \mathrm{mL}^{-1}\right)$ was measured at different time points $(5-60 \mathrm{~min})$. It could be seen that binding took about $15 \mathrm{~min}$ to reach $90 \%$ of the equilibrium level. To investigate the selectivity of RNase A nanoMIPs, lysozyme $(\mathrm{MW}=14.3 \mathrm{kDa}, \mathrm{pI}=9.3), \beta$-Lactoglobulin $(\mathrm{MW}=18.4 \mathrm{kDa}, \mathrm{pI}=$ 5.1) and hemoglobin ( $\mathrm{MW}=64.5 \mathrm{kDa}, \mathrm{pI}=6.8)$ were selected as reference proteins. The results illustrated that the nanoMIP had higher selectivity towards RNase A, indicating the binding sites created on the nanoMIP were specific to RNase A (Fig. S4c).

Next, we compared the inhibition efficiency of nanoMIP 4 with the commercial protein RNase A inhibitor. The nanoMIP $4\left(5 \mathrm{mg} \mathrm{mL}^{-1}\right)$

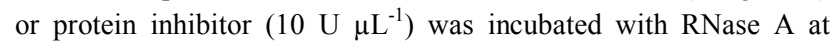
different concentrations ( 0 to $10 \mathrm{ng} \mu \mathrm{L}^{-1}$ ) in $2 \mu \mathrm{L}$ of PBS buffer. The amount of active RNase A was determined using the RNase A activity kit as plotted in Fig. 2b. When the total amount of RNase A was less than $10 \mathrm{ng}$, the nanoMIPs was able to achieve similar inhibition efficiency as the protein inhibitor, and $>90 \%$ of RNase A was inactive. The results confirmed that with the cavities of complementary shape, size, and chemical functional groups, the nanoMIPs could recognize and block the active sites of RNase A. However, it was also noted that when the RNase A was raised to 20 $\mathrm{ng}\left(10 \mu \mathrm{g} \mathrm{mL}^{-1}\right)$, the non-inhibited RNase A rose remarkably for the nanoMIPs while the increase was insignificant for the protein inhibitor. The inhibition assay showed that $2.5 \mathrm{ng}$ of RNase A was still active, which corresponded well with the binding capacity of the nanoMIPs. The binding isotherm curve (Fig. S4a $\dagger$ ) showed that 10 $\mu \mathrm{g}$ of nanoMIPs was able to bind $17.5 \mathrm{ng}$ of RNase $\mathrm{A}$ at the concentration of $10 \mu \mathrm{g} \mathrm{mL}^{-1}$, therefore $2.5 \mathrm{ng}$ of RNase A remained unbound. The inhibitory potency of the nanoMIPs could be improved by either increasing the concentration of nanoMIPs or further optimizing the compositions and categories of functional monomers used to synthesize the nanoMIPs.

Finally, the feasibility of applying the nanoMIPs to inhibit RNase A was tested in RT-PCR assays. The RT-PCR was carried out using the miRCURY LNA ${ }^{\mathrm{TM}}$ Universal RT microRNA PCR kit. The synthetic microRNA UniSp6 was used as the template to avoid any prior RNase A contamination, and the two-step assay was based on universal reverse transcription followed by real-time PCR amplification. One $\mu 1$ of RNase A at different concentrations ( 0 to 50 ng $\mu \mathrm{L}^{-1}$ ) were spiked into a $10 \mu \mathrm{L}-\mathrm{RT}$ reaction mixture. For comparison, three types of RT assays were performed: 1) without any inhibitors; 2) with protein inhibitor; 3) with nanoMIPs. Realtime PCR was then carried out using the cDNA products from the RT step, and the reaction was detected by accumulation of a fluorescent signal as shown in Fig. 3. The Ct value, which is defined as the number of cycles required for the fluorescent signal to cross the threshold, is summarised in Table. 1. As the Ct levels are inversely proportional to the amount of target nucleic acid in the sample, they were used to evaluate the inhibitory effect of the nanoMIP and protein inhibitor. 


\section{Journal Name}

(c)

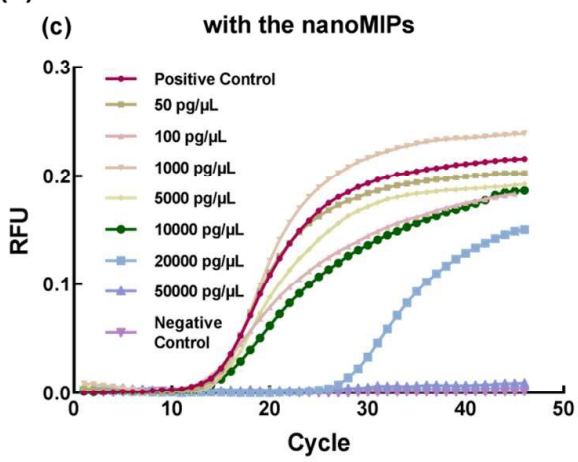

(a)

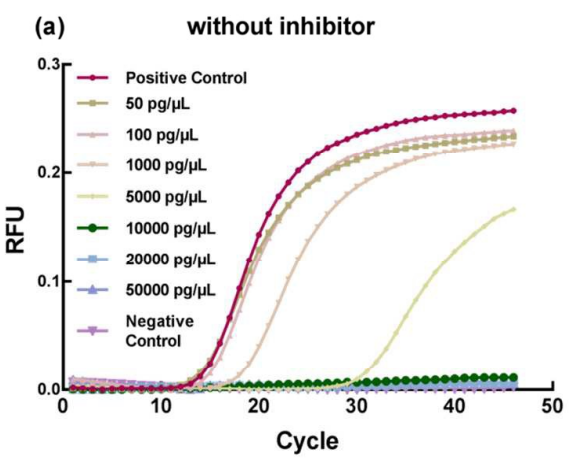

(b)

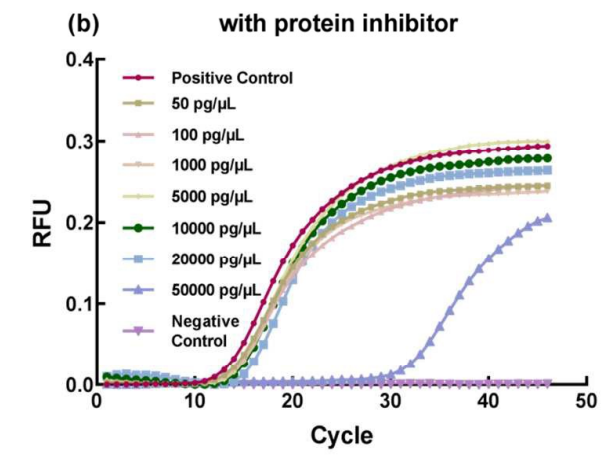

\section{COMMUNICATION} (1)

Fig. 3. The real-time RT-PCR assays with (a) different concentrations of RNase A without adding inhibitors; (b) different concentrations of RNase A mixed with protein inhibitor; (c) different concentrations of RNase A mixed with nanoMIPs. Y-axis represents fluorescence intensity after each PCR cycle, which corresponds to the amount of PCR products in the reaction tube.

For the RT assay without any inhibitors, the $\mathrm{Ct}$ value did not show a significant change when less than $100 \mathrm{pg}$ of RNase A was added, indicating that abundant target microRNA remained intact in the sample. As RNase A was above $1 \mathrm{ng}$, the Ct increased considerably, showing that a large amount of microRNA was degraded by the RNase A (Fig. 3a). Whereas when the protein inhibitor was mixed with RNase A, the Ct value showed a remarkable right-shift at $50 \mathrm{ng}$ of RNase A (Fig. 3b), suggesting that the protein inhibitor could efficiently inhibit at least $20 \mathrm{ng}$ RNase A. In comparison, when the nanoMIP was applied, a notable change in $\mathrm{Ct}$ value occurred at 20 ng of RNase A (Fig. 3c), implying the nanoMIP successfully inhibited $10 \mathrm{ng}$ of RNase A. These results agreed well with the inhibiton test which showed that the nanoMIP was able to achieve comparable inhibition efficiency as the protein inhibitor if the total amount of RNase A was less than $10 \mathrm{ng}$. It was also worth noting that the positive control of all the three types of RT assays showed a similar Ct value, indicating that nanoMIP did not interfere with other
Table 1. Ct values for the three types of RT-PCR assays.

\begin{tabular}{cccc}
\hline \multirow{2}{*}{$\begin{array}{c}\text { RNase A concentration } \\
\left(\mathbf{p g} \boldsymbol{\mu} \mathbf{L}^{-1}\right)\end{array}$} & \multicolumn{3}{c}{$\mathbf{C t}$ value } \\
\cline { 2 - 4 } & $\begin{array}{c}\text { Without RNase A Protein } \\
\text { inhibitor }\end{array}$ & $\begin{array}{c}\text { MIP } \\
\text { inhibitor }\end{array}$ & inhibitor \\
\hline 0 & 14.6 & 14.3 & 14.5 \\
50 & 14.5 & 14.7 & 14.8 \\
100 & 15.3 & 15 & 14.7 \\
1000 & 18.8 & 15.1 & 15.2 \\
5000 & 31.5 & 15 & 15.1 \\
10000 & NA & 15.3 & 15.4 \\
20000 & NA & 16.2 & 28.7 \\
50000 & NA & 31 & N/A \\
\hline
\end{tabular}


enzymes present in the reaction mixture such as reverse transcriptase and DNA polymerase.

\section{Conclusions}

In summary, water-compatible RNase A nanoMIPs were successfully synthesized by solid phase method with an optimized composition. These results suggested that the nanoMIPs have high binding specificity towards RNase A, and could effectively prevent degradation of RNA. To the best of our knowledge, this was the first time that the nanoMIPs were used as RNase A inhibitor in RT-PCR assays. Further work will focus on improving the binding capacity of RNase A by changing the compositions and categories of functional monomers, which will make it truly comparable with commercial protein inhibitor. We anticipate that the nanoMIPs, as a low-cost and thermal-stable enzyme inhibitor, will become a valuable tool in routine biological assays.

\section{Conflicts of interest}

There are no conflicts to declare.

\section{Acknowledgments}

This work was financially supported by the Villum Fonden, Denmark, Project No. 13153.

\section{Notes and references}

1 I. Van Der Auwera, D. Peeters, I. H. Benoy, H. J. Elst, S. J. Van Laere, A. Prové, H. Maes, P. Huget, P. Van Dam, P. B. Vermeulen and L. Y. Dirix, British Journal of Cancer, 2010, 102, 276-284.

2 F. Postollec, H. Falentin, S. Pavan, J. Combrisson and D. Sohier, Food Microbiology, 2011, 28, 848-861.

3 D. Knezevic, A. D. Goddard, N. Natraj, D. B. Cherbavaz, K. M. Clark-Langone, J. Snable, D. Watson, S. M. Falzarano, C. Magi-Galluzzi, E. A. Klein and C. Quale, BMC Genomics, 2013, 14, 1-12.

4 T. Svingen, H. Letting, N. Hadrup, U. Hass and A. M. Vinggaard, PeerJ, 2015, 3, e855.

5 M. Saramago, C. Bárria, R. F. dos Santos, I. J. Silva, V. Pobre, S. Domingues, J. M. Andrade, S. C. Viegas and C. M. Arraiano, Current Opinion in Microbiology, 2014, 18, 105115.

6 G. I. Yakovlev, V. A. Mitkevich and A. A. Makarov, Molecular Biology, 2006, 40, 867-874.

7 B. D. Smith, M. B. Soellner and R. T. Raines, Journal of Biological Chemistry, 2003, 278, 20934-20938.

8 S. P. Velagapudi, Y. Luo, T. Tran, H. S. Haniff, Y. Nakai, M. Fallahi, G. J. Martinez, J. L. Childs-DIsney and M. D. Disney, ACS Central Science, 2017, 3, 205-216.

9 E. Rosta, W. Yang and G. Hummer, Journal of the American Chemical Society, 2014, 136, 3137-3144.

10 K. J. Thompson, J. Zong and G. A. Mackie, Journal of Bacteriology, 2015, 197, 477-482.
F. Sorgeloos, B. K. Jha, R. H. Silverman and T. Michiels, PLoS Pathogens, PLoS pathogens,2013,9,6.

A. Mizrak, M. F. Bolukbasi, G. B. Ozdener, G. J. Brenner, S. Madlener, E. P. Erkan, T. Ströbel, X. O. Breakefield and O. Saydam, Molecular Therapy, 2013, 21, 101-108. H. Zhang, Polymer (United Kingdom), 2014, 55, 699-714. W. Ji, M. Zhang, Q. Gao, L. Cui, L. Chen and X. Wang, Analytical and Bioanalytical Chemistry, 2016, 408, 53195328.

J. Ashley, Y. Shukor and I. E. Tothill, The Analyst, 2016, 141, 6463-6470.

X. Feng, J. Ashley, T. Zhou, A. Halder and Y. Sun, RSC Advances, 2018, 8, 2365-2372.

Y. Hu, J. Pan, K. Zhang, H. Lian and G. Li, TrAC - Trends in Analytical Chemistry, 2013, 43, 37-52.

H.-B. Zheng, J.-Z. Mo, Y. Zhang, Q. Gao, J. Ding, Q.-W. Yu and Y.-Q. Feng, Journal of Chromatography A, 2014, 1329, 17-23.

A. Cutivet, C. Schembri, J. Kovensky and K. Haupt, J.Am.Chem.Soc, 2009, 131, 2-5.

H. Zhang, J. Jiang, H. Zhang, Y. Zhang and P. Sun, ACS Macro Letters, 2013, 2, 566-570.

Y. Liu, S. Wang, C. Zhang, X. Su, S. Huang and M. Zhao, Analytical Chemistry, 2013, 85, 4853-4857. F. Canfarotta, A. Poma, A. Guerreiro and S. Piletsky, Nature protocols, 2016, 11, 443.

D. Gagné and N. Doucet, FEBS Journal, 2013, 280, 55965607.

Y. Liu, G. Gotte, M. Libonati and D. Eisenberg, Nature Structural Biology, 2001, 8, 211-214. 
Table of Entry

We showed that molecularly imprinted nanoparticles (nanoMIPs) synthesized for RNase A could efficiently inhibit the activities of the RNase in reverse transcriptase polymerase chain reactions (RT-PCR), demonstrating that the tailor-made nanomaterials are very promising for use in routine biological assays.

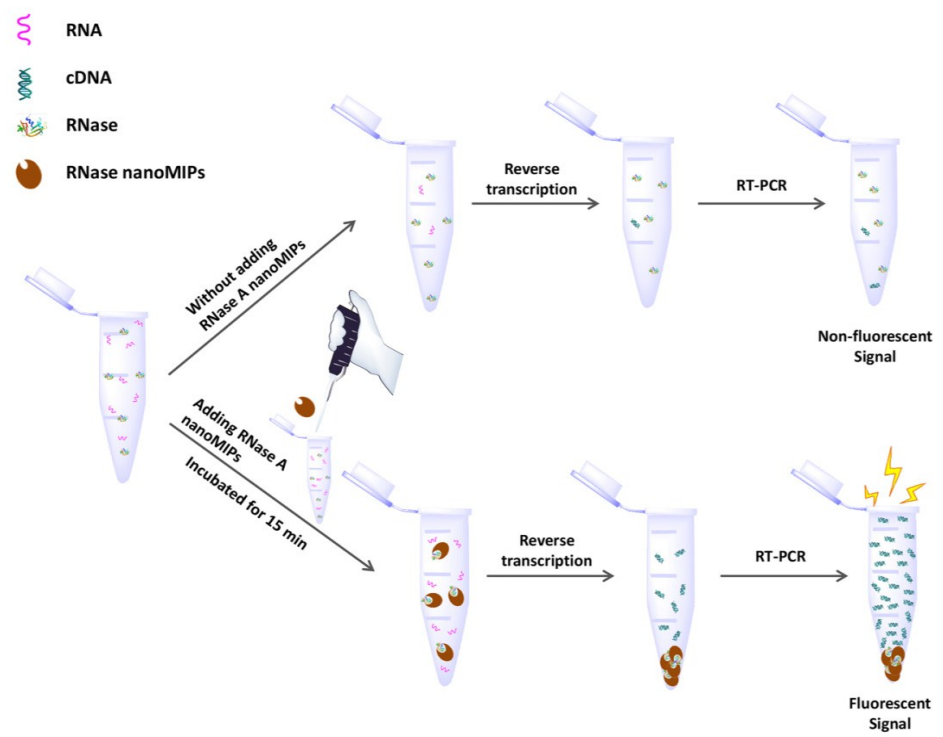

View Article Online DOI: 10.1039/C8AN00711J 